\title{
Late Roman Forest in the Delta of the River Po (Italy): Remote Sensing and 3D Maps Computation for Palaeoenvironmental Reconstruction
}

\author{
Giovanna Bucci ${ }^{1,2}$ \\ 1 Cultural Heritage Department, University of Padova, PD 35139 Padova, Italy; giovanna.bucci@unipd.it \\ 2 Confédération Mondiale des Activités Subaquatiques, Federation ITA F07 A.CDCI., BO 40127 Bologna, Italy
}

Received: 2 June 2020; Accepted: 11 July 2020; Published: 13 July 2020

\begin{abstract}
Literary and historical sources provide information about Late Roman forests in the Delta of the River Po, in the district of Ferrara (Italy), between Vicus Aventiae (Voghenza), Sandalo, Gambulaga, Caput Gauri (Codigoro) and Castrum Cumiacli (Comacchio). Toponymy, archaeological excavations and geoarchaeological studies support the palaeoenvironmental reconstruction of this land. In this work, after a brief examination of the ancient texts, we are going to introduce some new data concerning archaeobotanical evidence, detected by remote sensing in combination with direct surveys (on land and underwater). On the technical side, we are going to present a geomatic application for underwater measurements of ancient trunks related to discoveries in the palaeo-watercourses of the River Po (geomatic measurements, thanks to remote sensing surveys, allows us to have detailed length and diameters of trunks and trees, which are not always visible and detectable while diving) together with some satellite elevation measurement of the river banks and 3D map supported by geocomputation. Thanks to botanical data, we are able to illustrate the local context of the paleoenvironmental/archaeological sites, offering a reconstruction of the landscape and of the use of the wood.
\end{abstract}

Keywords: forest; Late Antique; archaeology; palaeoenvironment; remote sensing; geocomputation; palaeowatercourses; Ferrara

\section{Introduction and Historical Sources}

The open land of Pianura Padana, during the Late Antiquity and the Middle Ages, was characterized by rivers and watercourses with paludes and piscariae, between forests and woods. The complex hydrographic system was surrounded by a manifold botanical world. Data concerning forests in Late Antiquity in Italy are not abundant [1-3], but thanks to our recent studies we have been able to contribute to the knowledge of this historical phase and reconstruct a detailed panorama of the river banks of the Eridanus (ancient Po) between Voghiera and Portomaggiore, reaching the area of Codigoro and Comacchio (small towns in Ferrara district).

The innovative aspect of this research consists of introducing remote sensing technique with indirect measures of landscape and botanical findings with big dimensions, in order to make a contribution for the reconstruction of ancient forests, combined with satellite image analysis and remote sensing elevation data from Google Earth Pro 7.3.3.7699 (64-bit), in the new perspective of Waterscape Archaeology.

The focus of this study is a specific investigation with thematic analysis about the remains of the Late Antique and Medieval Forest with traditional and innovative methodologies. We are going to explain some details about palaeoenvironmental context of the River Eridanus, going more deeply into some topics and discovers of our project Underwater archaeology of inland waters performed 
at Lago Tramonto, Gambulaga (the site already published on 2018, within our project) [4]. Here we present some comparisons related to other local artificial lakes in the palaeo-watercourse of the river Po, like Lago Campanella, near Sandolo and other palaeo-watercourses attested near Voghiera and near Comacchio, adding some brief considerations about wood findings in the Codigoro area [5-8] (Figure 1).

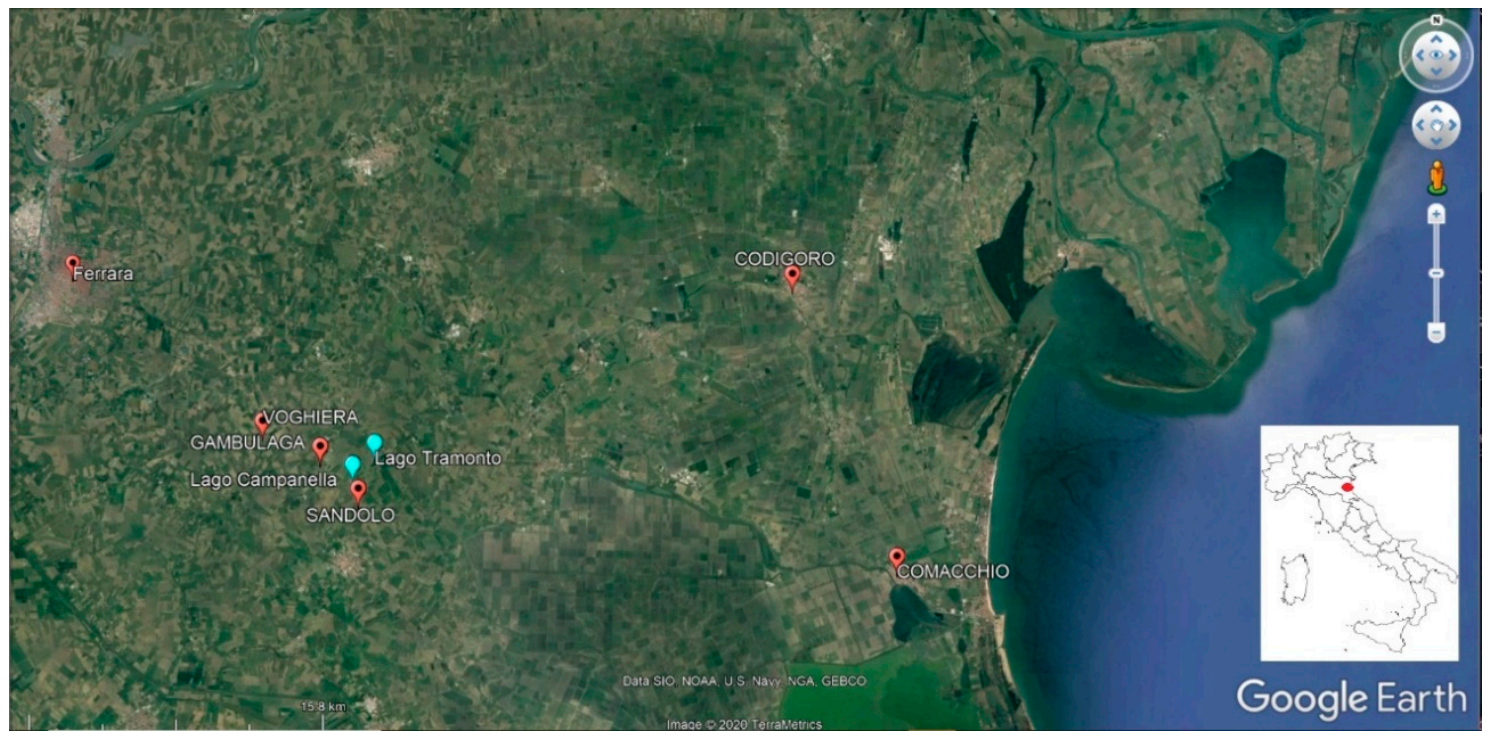

Figure 1. Google Earth satellite image 2018, Ferrara district, Italy: the main sites mentioned in this work (accessed 27/02/2020).

The above-mentioned project is coordinated by the authors and it is focused on experimentation of the synergy of scientific disciplines and combined methodologies and techniques for underwater cultural heritage of the inland waters. It is a collaboration between the scuba Federation ITA F07-CMAS Diving Center Italia, Confédération Mondiale des Activités Subaquatiques Soprintendenza Archeologia, Belle Arti e Paesaggio per la città metropolitana di Bologna e le province di Modena, Reggio Emilia e Ferrara, Archaeology sector, University of Padova, Cultural Heritage Department, Underwater Archaeology Laboratory (LAS).

The forest, from Roman Time to the Middle Ages, was developed circum ripa Padi et litora Maris Hadriatici (close to the banks of the River Po and the coast of the Adriatic Sea), as mentioned by Vitruvius (De Architectura, II, 9, 14) and Cassiodorus (Variae, V, 17, 5). S. Patitucci Uggeri, studying ancient document from Pomposa (Comacchio district) [9,10], explains that there were some sylvae attested in official mediaeval documents, belonging to diploma and emphyteusis in Pomposa: a silva (wood, forest) in insula queae vocatur Adriana (in the island called Adriana) near Pomposa, a silva que vocatur de Montone (a forest called of the Montone) near Goro, a nemus Capitisgauri (a wood of Codigoro), a silva vocata Vaccolino (a forest called Vaccolino), near the selvosa insula Pomposiana (Pomposiana Island with dense forest). In this panorama, actually, we are able to add another silva, located between Voghenza and Portomaggiore, following the Eridanus, attested by archaeological evidences.

As underlined in our last publication about Lago Tramonto, the local toponymies give some suggestions about the old presence of a local forest; Runco, for example, from the verb runcare, to cut (referring to prune trees, place already known as Alberolungo-long tree), Rovereto, from roburetum, wood of oaks [11,12].

\section{Topographical and Geoarchaeological Context}

The Southern Palaoeo-watercourse of the River Po, the Eridanus runs across the ancient sites of Vicus Aventiae (Vochiera-Voghenza), Gambulaga, Roburetum (Rovereto), turning to South to Castrum Cumiacli (Comacchio) from the Etruscan Period until the Late Antique Phase. In the sector between Gambulaga 
and Rovereto the river was modified by the human presence. The riverbed shows anthropized banks modelling the river edges, arranged according to a rectilinear flow Southwest-Northeast $[4,13]$ (Figure 2).

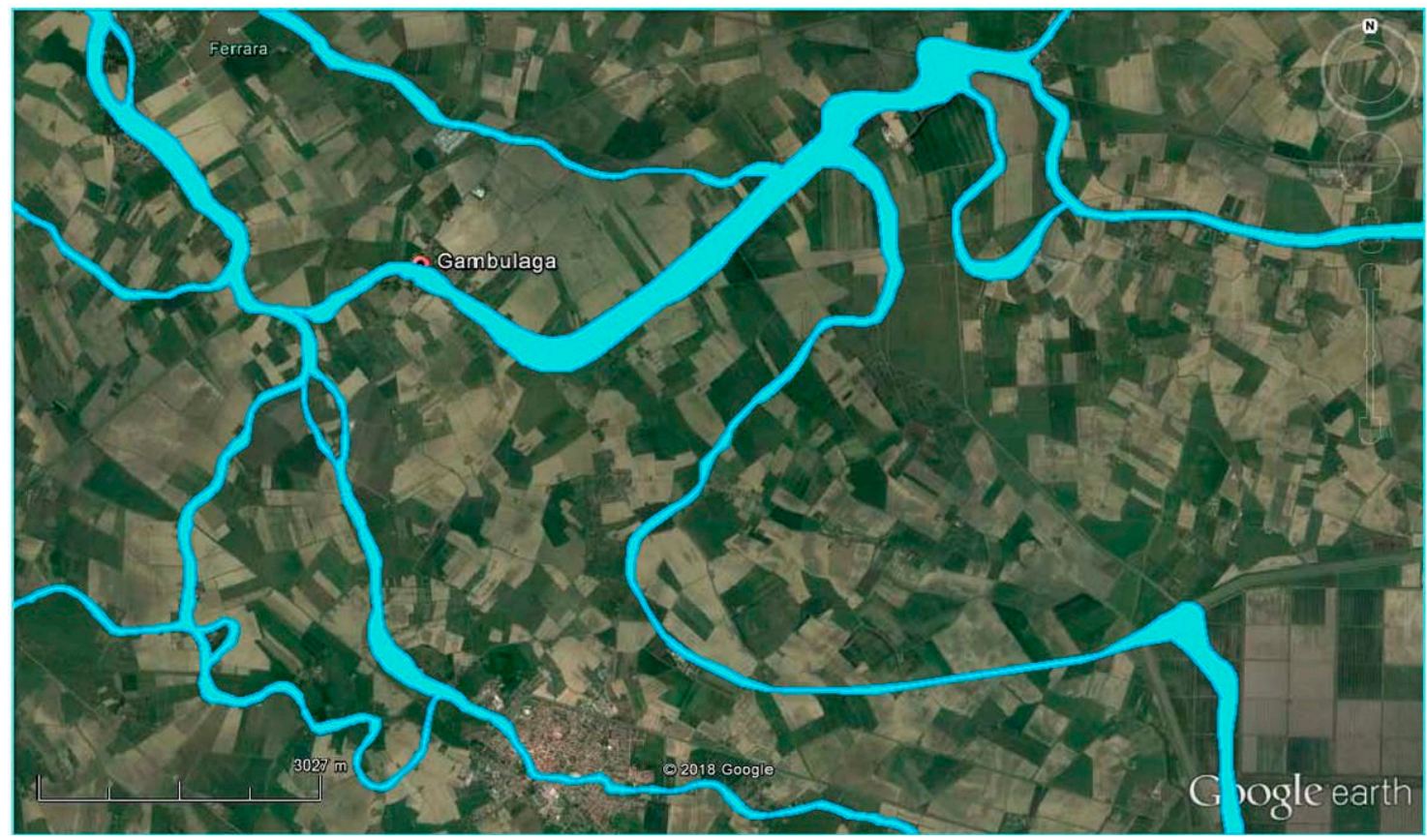

Figure 2. Gambulaga - Portomaggiore (FE). Main paleoalvei North of Portomaggiore: above the Eridanus with ancient straight artificial rectification, below the course of Sandalo river (elaboration G. Bucci on Google Earth 2018 satellite image).

The presence of the vicus, Voghenza (with houses, necropolis, and brick furnaces) (http://www. archeobologna.beniculturali.it/Ferrara/area.htm\#Necropoli_Romana_di_Voghenza), and the site of the necropolis of the Fadieni in Gambulaga (http://www.archeobologna.beniculturali.it/mostre/gambulaga. $\mathrm{htm})$, connected by rivers and channels, already demonstrate the remarkable diffusion of the Roman and Late Roman Anthropic Phase [14]. The river was a jointing natural element used for transport, commerce, and every day economic life. Reading the local stratigraphy, we see the Eridanus bank developed on a multilevel structure, mainly natural, with artificial devices.

In Voghiera, for example, we see some layers of sand, coming from overflow of the river (Figure 3) $[5,8,15]$.

Moving to South, and going to Gambulaga, in Tramonoto Lake (Figure 4), after detecting the morphology and direction of the north bank margin, with underwater surveys with a direct draw on site, it is possible to see the stratigraphy in a largely preserved state, despite the dredging works of the old dismissed sand quarry. To define a microstratigraphy for a better comprehension we completed some geoarchaeological drillings (for a detailed description, please see bibliography $[4,16]$ ).

The sedimentology interpretation describes an upper modern level of silty clay covering a system of palaeosoils and alluvial layers. Three main anthropized levels are attested on site: at $-3.15 \mathrm{~m}$ a grey compact clay anthropic stratum (Late Antique), at $-5.40 \mathrm{~m}$ a thin violet clay layer with micro-carbonaceous cores and vegetal traces (palaeosoil-Roman Imperial Phase), at $-6.10 \mathrm{~m}$ a thick violet silty clay level with micro-carbonaceous cores and vegetal traces (palaeosoil-perhaps belonging to Protohistory). Following the slope of the actual bank, underwater, we see debris and accumulation of wood, trunk and fictile pieces belonging to Roman and Late Roman Period. On the Late Antique-Middle Ages levels there are some big trunks and parts of amphora. Thanks to our geo-archaeological computation, we reconstruct a synthesis of local stratigraphy with metrical references (Figure 5). 


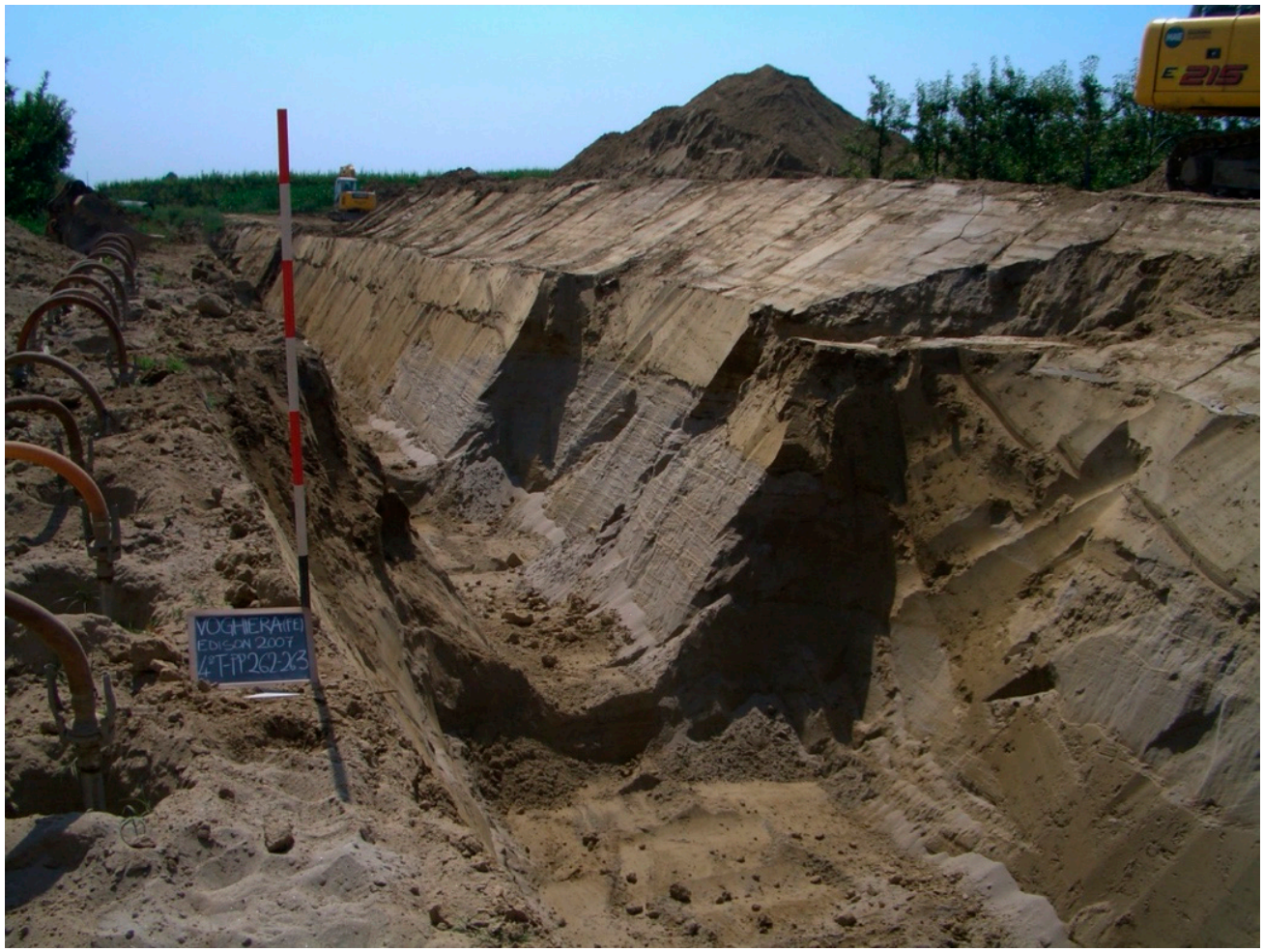

Figure 3. Voghiera (FE), Street P 29, West side: overflow levels with sandy deposit (photo G. Bucci).

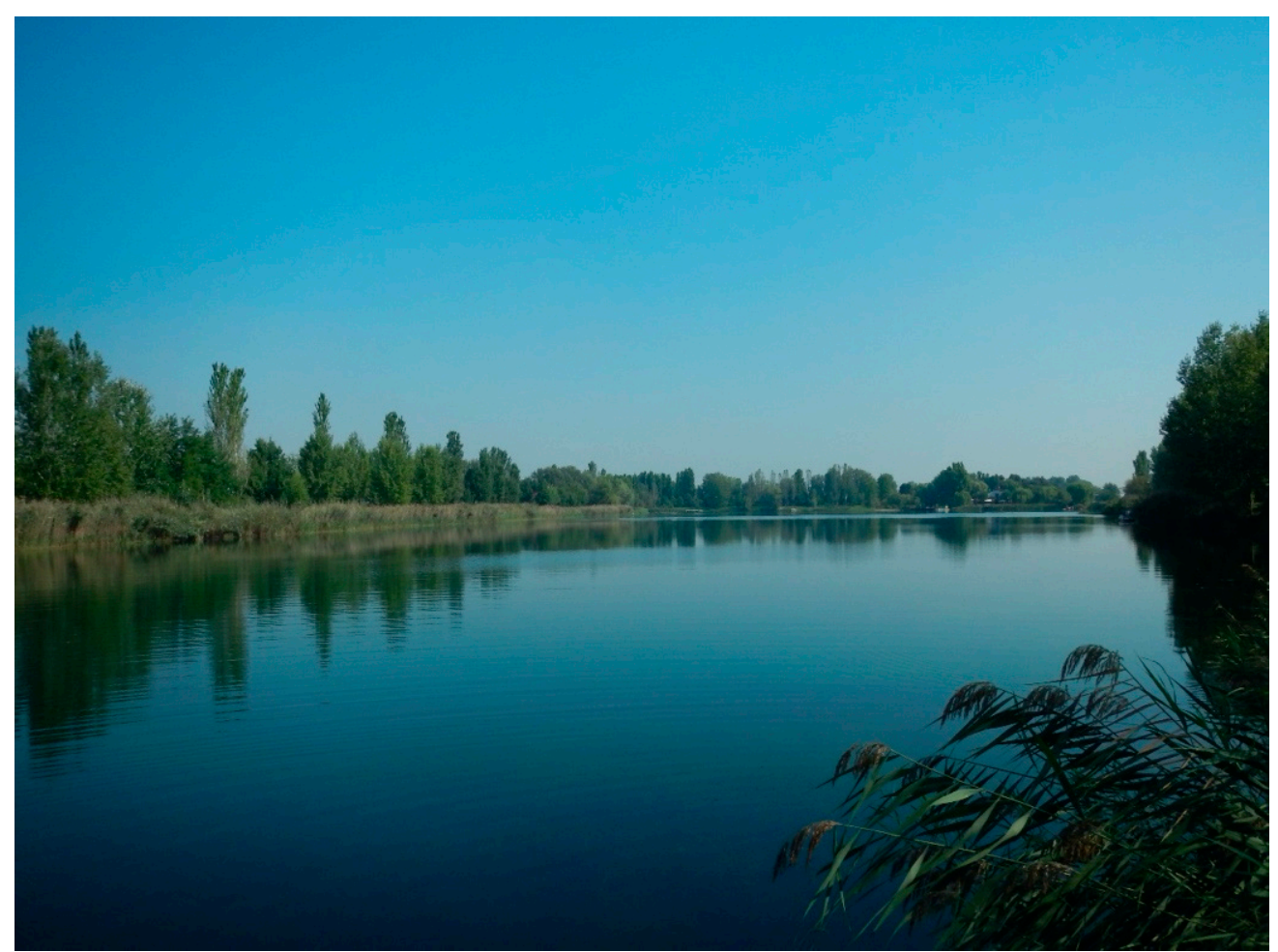

Figure 4. Gambulaga-Portomaggiore (FE), Lago Tramonto. View from Southwest side (photo G. Bucci). 


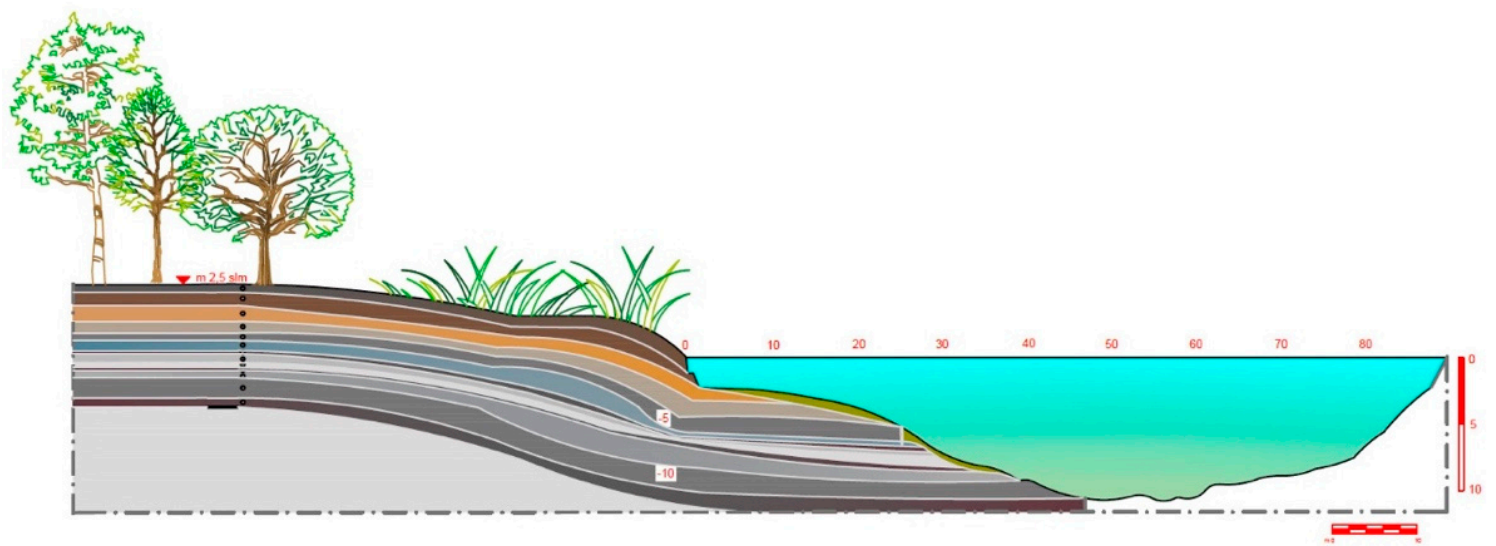

Figure 5. Gambulaga-Portomaggiore (FE), Lago Tramonto. Northern side, reconstruction of the stratigraphic section with the current bank morphology of the lake with artificial cutting due to the excavation of the quarry (G. Bucci).

Regarding the discussion of the site we invite you to read our 2018 reportage [4].

Our focus now is going on the wood findings.

During the underwater surveys we documented not only the wood structure the Late Roman bank, but also the presence of very big trunks all oriented in the direction of the river current, clear evidence of a large flood that swept over the river edges. Together with the botanical findings, we have found pottery fragments belonging to different classes of objects: amphorae, containers for daily use, fragments of bricks, tiles and bricks (Figures 6 and 7)).

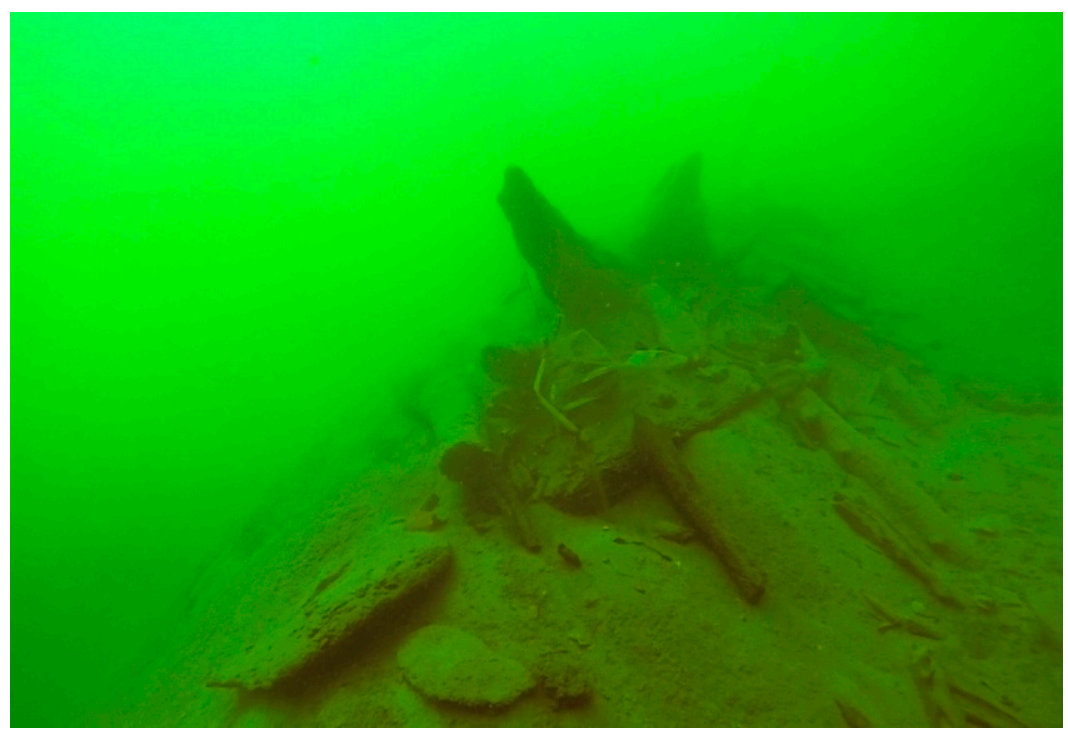

Figure 6. Gambulaga-Portomaggiore (FE), Lago Tramonto. Northern side, underwater debris flow with trunks, wood with traces of processing and binding, Roman bricks, Late Roman pottery, animal bones (photo G. Bucci). 


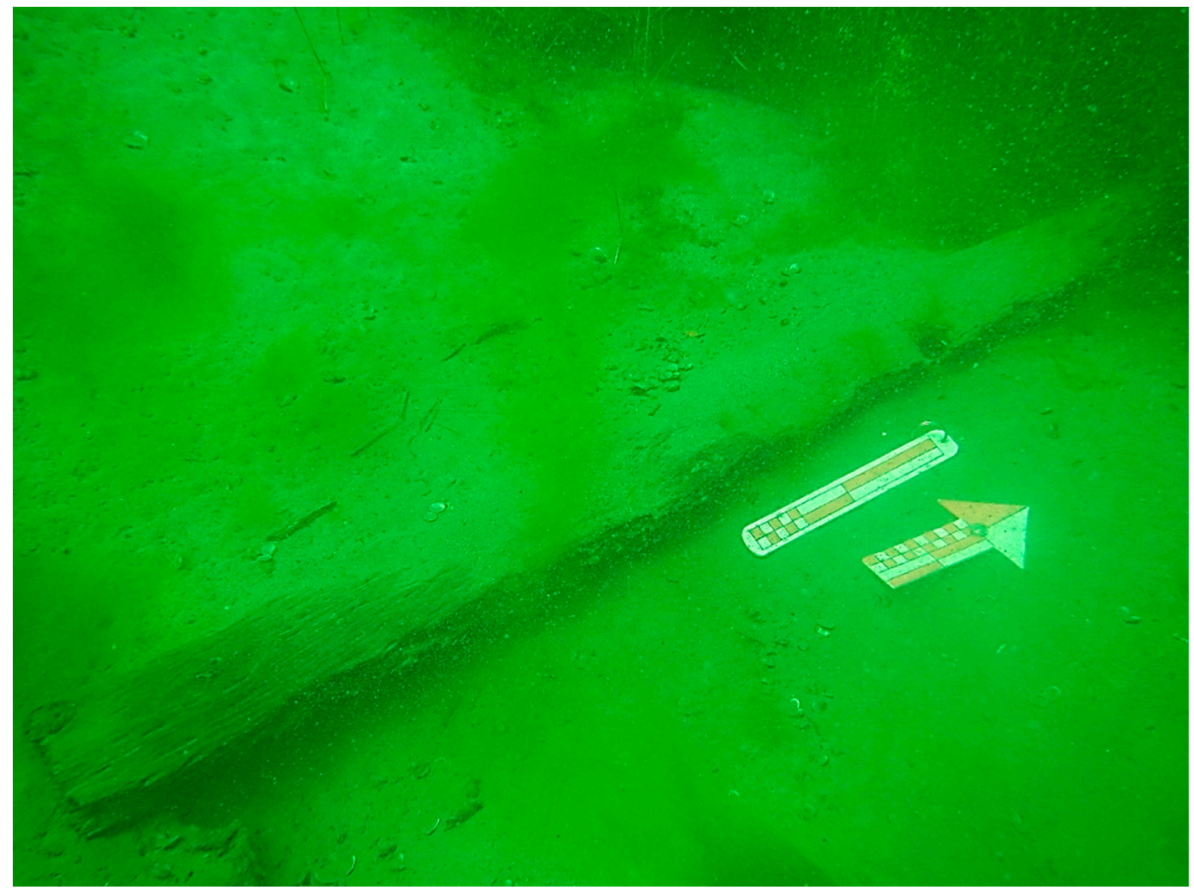

Figure 7. Gambulaga-Portomaggiore(FE), Lago Tramonto. Northern side, wood beam (photo G. Bucci).

\section{Materials and Methods}

Our research was completed thanks to a great scientific synergy between many disciplines: mainly geology, archaeology and history, and palaeobotany from work in the libraries and at university, to the survey activities, with the help of remote sensing and geomatics (regarding remote sensing in landscape archaeology and studying relations between natural environment and archaeology, see the work of Campana Recording concerning the integration of new and old research methods [17]). Remote sensing technology has been applied through different instruments. On the land context, such as river banks, indirect studies begun by measuring elevation levels of the river coastal zones, areas of over flow, subject to natural rising up $[18,19]$.

From a technical point of view, once established the topographical points, in Google Earth Pro, opening "ruler", after positioning and saving a line with a name (we choose a sector of Km 1, corresponding to the section we need), we moved to "Modify" and selected "Show elevation profile"; in the lower part of the video a monochromatic cross section of the site appears, including a narrow indicating the check point position. This function is very useful and enables a very easy understanding of the local geomorphology. We detected the height of the river edges: a crucial datum for the occupation and anthropic development of housing and commercial system. In addition, the activity of transport with the towpath took place on the banks. The helciarius was walking with quadrupeds on the bank, holding a rope with which boats are towed from the ground along a waterway.

In our case we realized four sections (length $\mathrm{Km} \mathrm{1,00} \mathrm{ca.),} \mathrm{individuating} \mathrm{the} \mathrm{highest} \mathrm{topographical}$ areas, attesting river depositional layers, fluvial islands and main banks. The North margin of the Eridanus is the key point for the comprehension of the ancient anthropogenic living/residential system during the Roman Period and Middle Ages. We detected a height above sea level between 3 and $2.5 \mathrm{~m}$ (Figure 8).

For a better comprehension of the ancient settlement system we constructed 4 3D plan-views, corresponding to the investigated areas thank to 3D Mapper (Figure 9). 


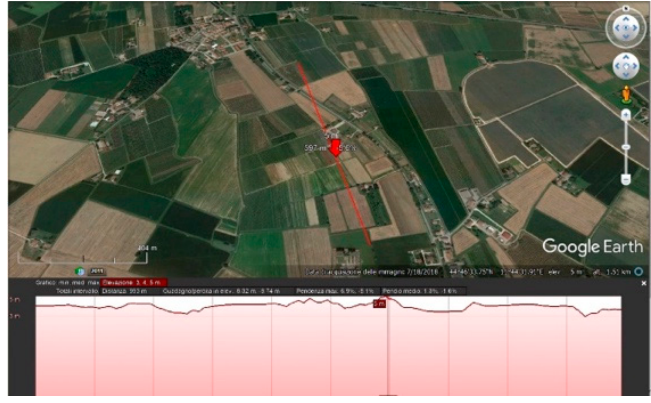

(a)

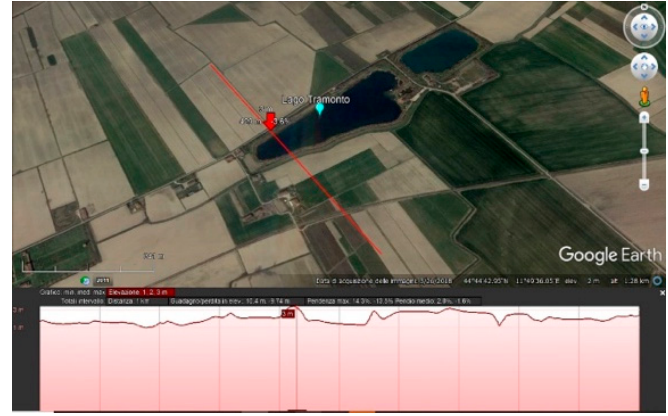

(c)

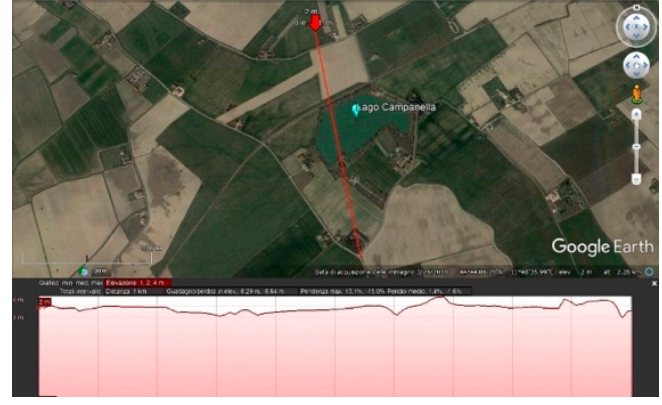

(b)

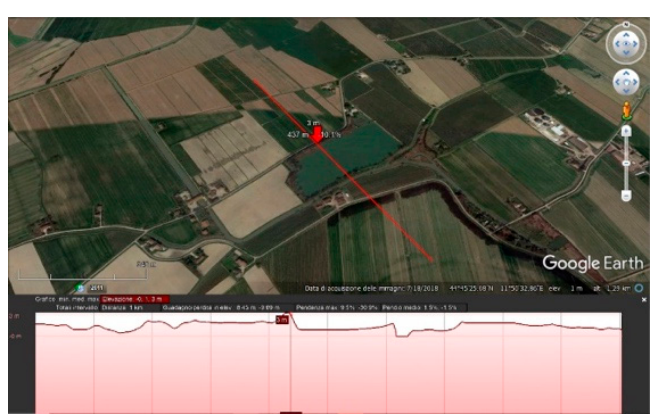

(d)

Figure 8. Google Erath satellite image 2018 with morphological elevation of the highest topographical areas, attesting river depositional layers. Voghiera (a), Lago Campanella in Sandolo (b), Lago Tramonto (c) and Lago della Gattola (d) in Gambulaga. The red line indicates the position of the cut section (accessed 02/03/2020, elaboration G. Bucci).

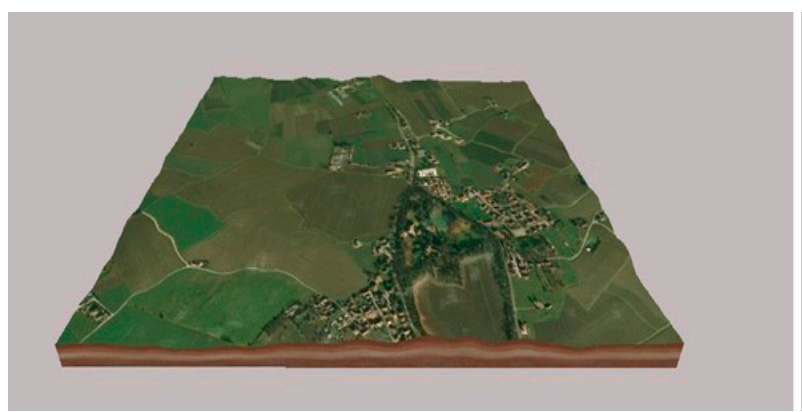

(a)

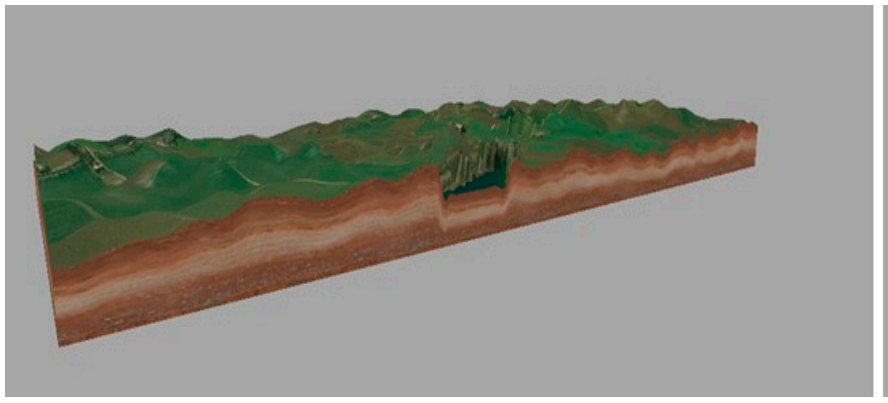

(c)

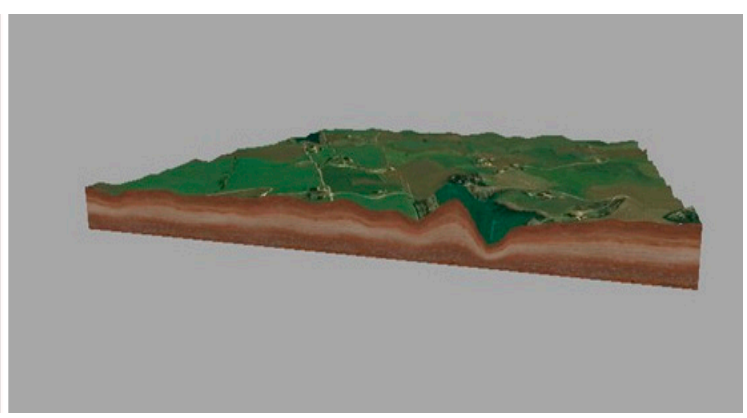

(b)

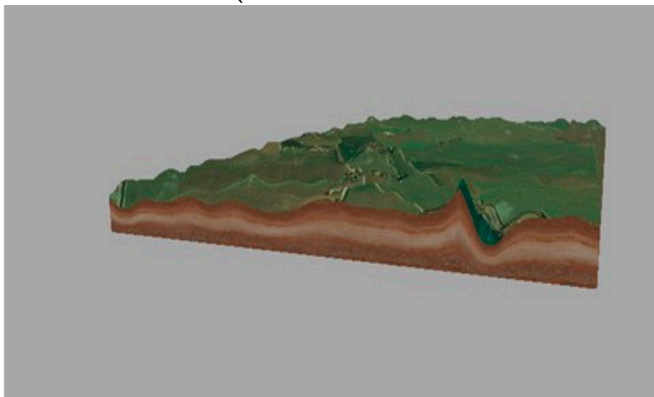

(d)

Figure 9. 3D maps with sections: Voghiera (a), Lago Campanella, Sandalo (b), Lago Tramonto (c), Lago Gattola (d), Gambulaga (elaboration G. Bucci with 3D Mapper online- $<$ a href="https: //www.maptiler.com/copyright/" target="_blank">(C) MapTiler</a>). 
The geocomputation of the morphological sections supported by $3 \mathrm{~d}$ plan-views show very well the altitude differences between the river edges, raised by the alluvial deposits, the old cut of the Eridanus river bed (actually lakes), and the system of small bumps on which the inhabited area has settled, as well places occupied by forest and sylvae.

Because of the strong presence of trunks and roots in the Lakes Campanella and Tramonto, knowing the underwater archaeological situation and the troubles of visibility, after some underwater direct investigations, we proceeded with echo side scan sonar surveys. We used an integrated instrument, echo sound scan sonar Humminbird 1198c SI Combo, reading data with the software HumViewer. The software while displaying the swath, allows us to measure the dimensions of findings and anomalies, thanks to the side image visualization thought utilities measure length/distance (Figure 10).

The documentation of the trunks was particularly complex due to the poor visibility on the lake bottom linked to the presence of algae and very fine clay in suspension [20]. For this reason, remote sensing investigations were very useful for the positioning and measurement of artificial and natural findings: it was impossible to work with a buddy system because of safety between divers and incompatibility of visual communication.

The software is free o line (http://humviewer.cm-johansen.dk/) and offers an easy approach to elementary geomatic measurements. The trunks are detectable as anomalies on the bottom of the lake, because of their shape and dislocation, generating shadows and showing anomalous morphology compared to the sedimentology on site.

Thanks to the echo side scan sonar and relative reading software, we were able to detect the lengths and diameters of the giant trunks directly in the studio, using a computer.

In Lake Tramonto, seven large tree trunks, numerous branches and twigs have been identified. Some of them bear traces of binding and processing.

The data fusion of the elements coming from direct and indirect investigations was completed by computer Asus Tuf with Intel COREi7, 8th Gen (2019), with Windows 10 for a multitask elaboration, integrating remote sensing technologies for the interpretation of landscape and waterscape ecosystems [21]).

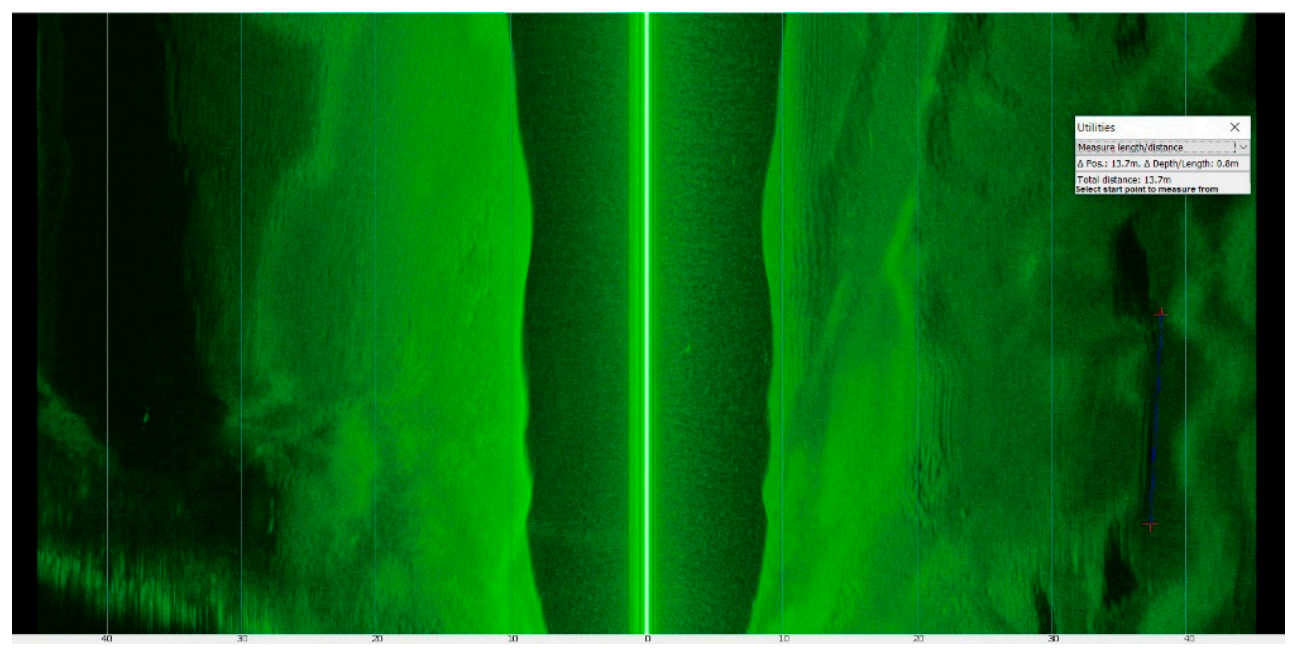

(a)

Figure 10. Cont. 


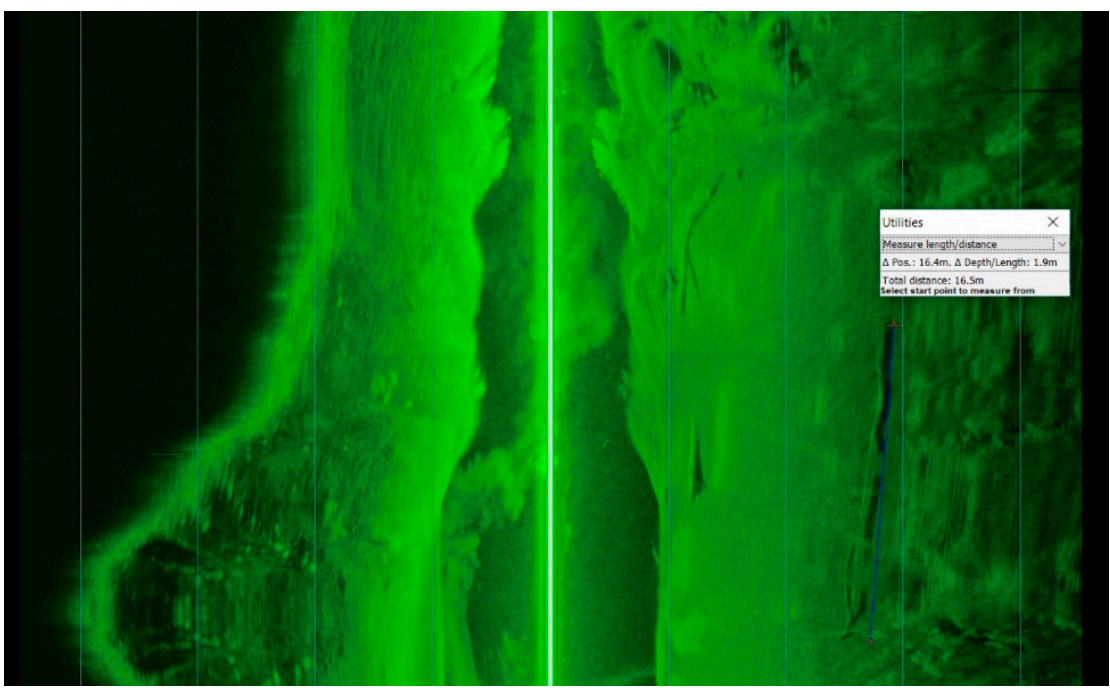

(b)

Figure 10. Gambulaga-Portomaggiore (FE), Lago Tramonto. Echo side scan sonar side image, red by the software Humviewer: measurements of the length of the trunks nos. 1 (a) and 5 (b).

\section{Discussion}

Big arboreal finds were discovered in Lago Campanella and in Lago Tramonto.

Particular attention should be paid to long oak trunks, which are important for length and diameter, attributable as habitat to the local or nearby forest, and from an archaeological point of view to the raw material to build pirogues.

Seven trunks of trees have been documented in Lake Tramonto between 2016 and 2019, at an average depth of between 5.0 and $10.5 \mathrm{~m}$. Trunk no.1 measures $13.7 \mathrm{~m}$ (Figure 11); trunk no.2, $8.3 \mathrm{~m}$; trunk no.3, $10.0 \mathrm{~m}$; trunk no.4, 7.9 m, trunk no.5, $16.5 \mathrm{~m}$; trunk no.6, $5.7 \mathrm{~m}$; trunk no.7, $8.0 \mathrm{~m}$. They are all dislocated along the North bank of the river. Some of them could be in a primary position, others have been transported by the stream of the flow, chronologically ascendable to the sixth century AD.

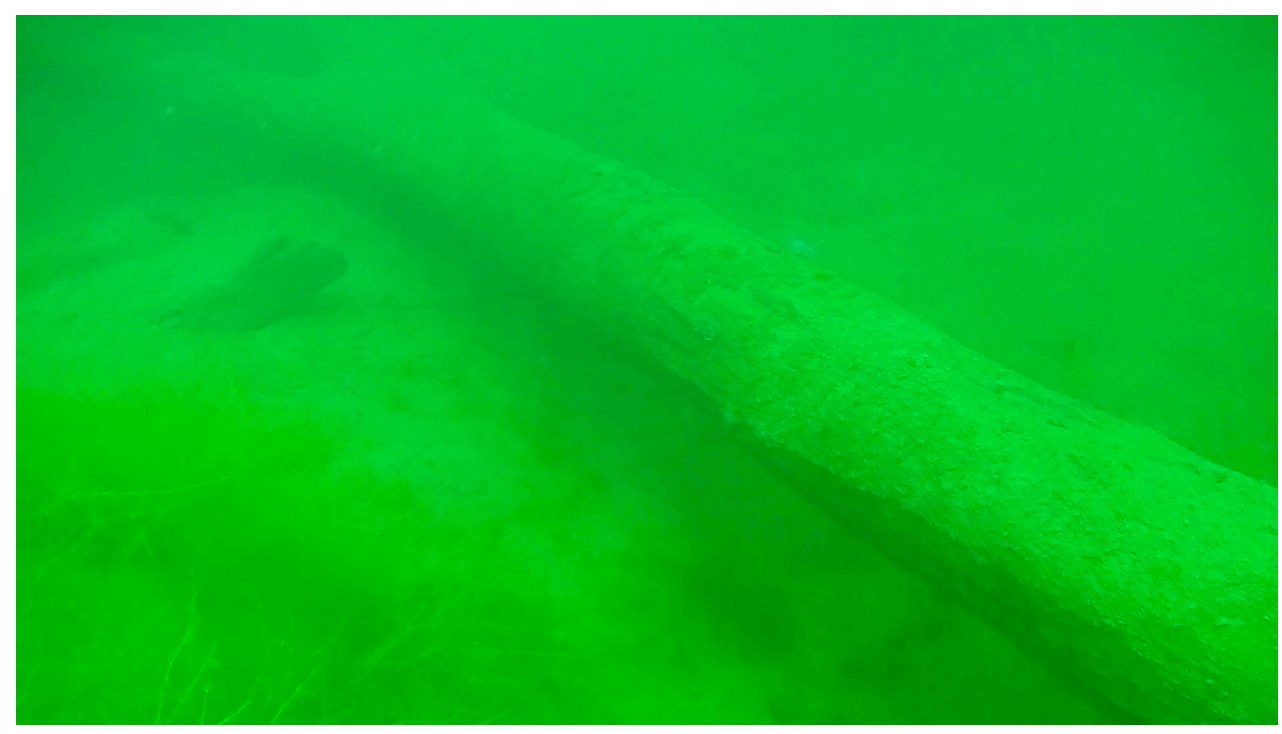

Figure 11. Gambulaga-Portomaggiore (FE), Lago Tramonto. Trunk no.1 (photo G. Bucci).

The big trees were used both to build means of transport (pirogue) for local traffic and for sale: perhaps there was a production centre of small wood boot, between Lake Campanella and Lake 
Tramonto (underwater, we found two bow or stern fragments, some starboards of monoxyle boats, and some partially excavated trunks) [12].

The trunks number 1 and number 5 are compatible with lengths and diameters (about $1.0 \mathrm{~m}$ ) of the pirogues discovered in the Ferrara area (more than 23 exemplars are already known: Valle Isola, Valle Rillo, Valle Ponti, Valle Pega (all in Comacchio area), Pomposa (Codigoro), Codigoro, Valle Volta (Massafiscaglia), Valle delle Gallare (Ostellato), Iolanda di Savoia. These boats, characterized by a common shape, similar measure, and the same kind of wood, can be traced back to the Late Antiquity and the Middle Ages [22,23] (Figure 12).

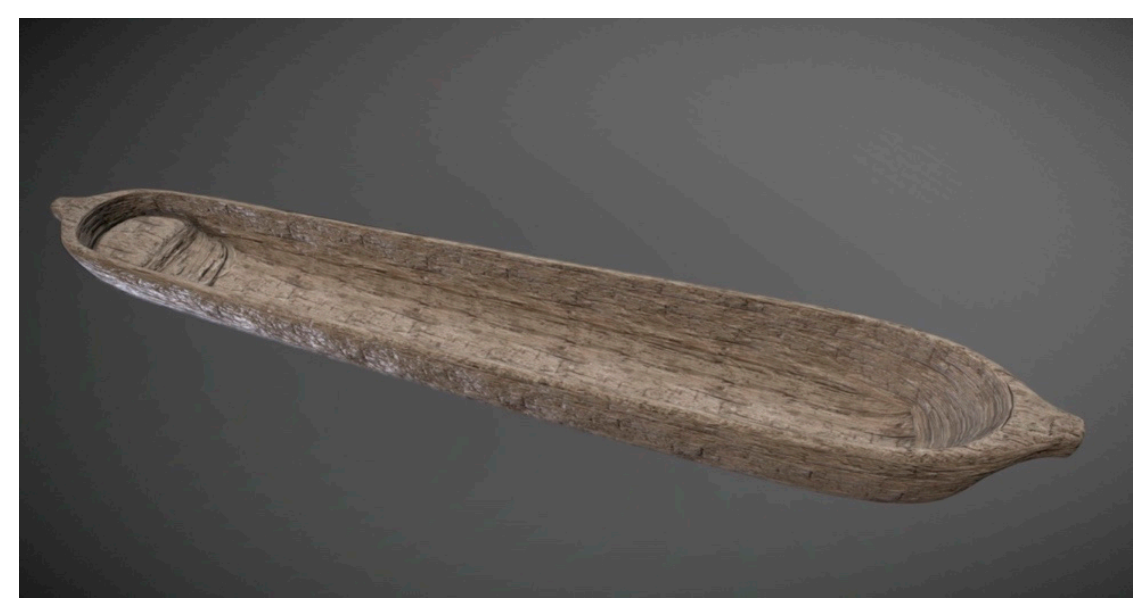

Figure 12. 3D reconstruction of Late Antique-Mediaeval Piroga by A. Martire [24].

The most evident comparison with similar botanical finds, still in the status of tree, quite similar in size and stratigraphic locations, are the woods from the nearby Campanella Lake (an artificial basin, born from quarry excavation in palaeowatercourse of the River Po) a few Km West of Lake Tramonto, located at the elbow of the meander of the ancient Po.

Very important studies for the Campanella lake were carried out by the University of Bologna during 1995, by L. Forlani and G. Nanni investigating the Sandalo wood fossil forest. After a cataloguing of 1519 wooden finds, including 147 trunks, 2 artefacts, 3 roots, 7 cork samples, 8 branches. There were parts of trees, shrubs, lianas, most of all deciduous broadleaf and conifer. In between the three main units identified by the palaeobotanists, the third sampling conserve elements dating back to the Roman period or the early Middle Ages [25]. The sampling carried out identifies Populus (Poplar-Salicaceae Family), Ulmus (Elm-Ulmaceae family), Salix (Willow_Salicaceae Family), Quercus (Oak_Fagaceae Family), Alnus glutinosa (Alder-Betulaceae Family), Juglans regia (Walnut-Juglandaceae Family), Juniperus communis (Juniper-Cupressaceae Family), Prunus (Cherry Laurel—Rosaceae Family).

The C14 analysis are dating back to a chronological span between the fourth and sixth century $\mathrm{AD}$. The same chronology is attested by pottery findings, Late Roman $V$ amphorae, found during direct underwater surveys.

In addition, the recent archaeological excavation in Comacchio (2014) [26], always on the palaeowatercoruse of the Eridanus, provided some information regarding the panorama of wood use for nautical means. The preliminary archaeobotanical analysis performed by M. Marchesini [27], superintendence palaeobotanist, on the planks of the sewn boat and on pieces of the monoxyl pirogue found close to the local bank, detected Oak wood (Quercus cf. robur - Fagaceae Family) and Elm (Ulmus-Ulmaceae family), respectively, the first to build the monoxyle pirogue, the second to build the boat. Considering the diffusion area of the plants from which the wood was obtained, it could be assumed that the river boat of Comacchio 2014 field - http://www.archeobologna.beniculturali.it/fe comacchio/imbarcazioni_2014.htm, was built in the Po area, northern than Santa Maria in Padovetere (exact location of the excavations). Elm trees were found also in Voghiera [28]. 
The monoxyle pirogue, given the construction type and the type of wood used, is likely to have been made in an area not too far from the place of discovery (Comacchio). Was it built in Gambulaga? Perhaps! The site might have been a pirogue factory, before the diluvium mentioned by Paulus Diaconus (Historia Langobardorum III.23). A Mediaeval iconographic support regarding pirogues construction is offered by the Bayeux Tapestry (Figure 13).

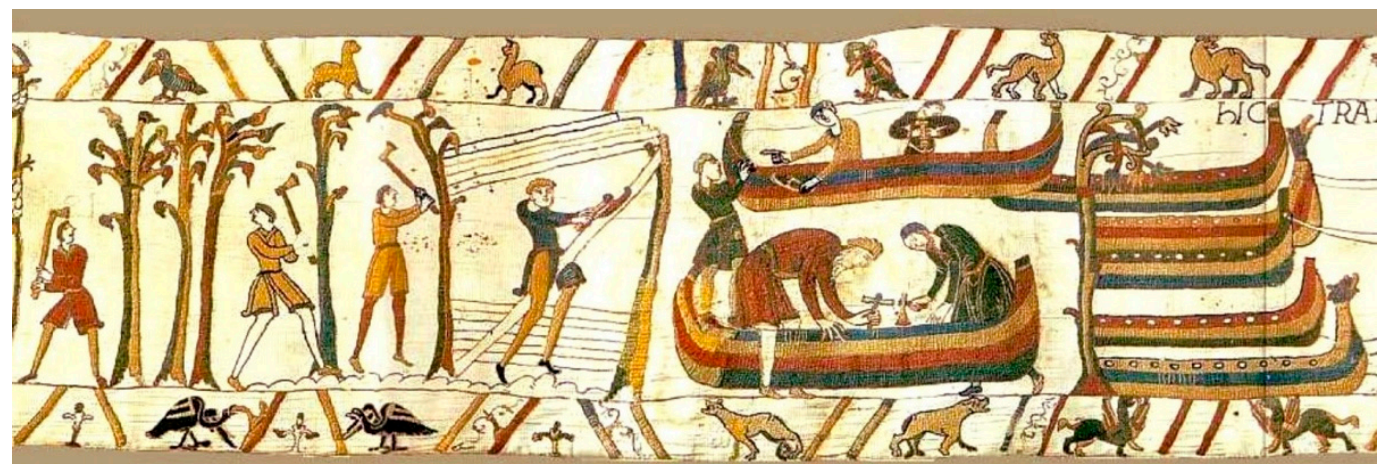

Figure 13. Bayeux Tapestry, detail of trees cutting to build pirogues and canoes (Eleventh Cent. AD) [29].

To complete the palaeobotany panorama, we need to add data coming from analysis performed by F. Facchini, University of Ferrara working on the sedimentological characterization of the samples catalogued during 2017 campaign [30]. In many samples we see the presence of seeds belonging to flora palustris (marsh flora), typical of inland waters, attesting an inter-distributive environment complex surviving on the northern side of the Eridanus bank itself in Gambulaga. The documented plants are floating hydrophytes, Nymphaea alba (White Water Lily), Sparganium erectum (Branched Bur-reed), helophytes Apium inondatum (Lesser Marshwort), and Typha latifolia (Bulrush).

\section{Conclusions}

The integrations of data coming from direct (surveys on sites, on land and underwater) and indirect investigation (remote sensing, satellite data elaboration, 3D map computation), together with botanical analysis and ancient sources studies, demonstrate the remarkable role of scientific synergy applied on archaeological research. This chance of collaboration demonstrates how anthropogenic occupation of this central part of the Delta can be traced back to Roman Imperial and to Late Antique Period: forests were not exclusively areas of woodland. They were being exploited for providing food, as fuel for furnaces for production of bricks, tiles (Pansiana production $[4,12,13]$ ) and glass making (from the area of Tramonto Like there is a pottery lamp decorated with the image of a local glass maker working at his furnace [31]), for manufacturing wooden goods, especially boats, and a means of water transport and carpentry.

The actual status of the river, surviving only as palaeo-watercourse, partially occupied by ex quarries of sand, conserves useful data for the reconstruction of the Late Antique phase. Certainly, the Eridanus, as one of the major rivers, was serving as communication corridor across the Southern Delta reaching the Adriatic Sea; it was a commercial route, more than a territorial dividing device.

The evidence attested between Lago Campanella and Lago Tramonto with a river level packed full of timber, testify the presence of the forest alongside the Eridanus. Many trunks come drifting down with the river. There are also sequences of uprights which mark the big destructive flow of the sixth century, reported by ancient sources. The data fusion allowed us to reconstruct a full botanical local context.

The Late Antique-Mediaeval silva was growing along the rivers, with Populus, Ulmus, Salix, Quercus, Alnus glutinosa, Juglans regia, Juniperus communis, Prunus (Poplar, Elm, Willow, Oak, Alder, Walnut, Juniper), Cherry Laurel). In between fluvial islands and meanders, small lakes and ponds housed marsh flora with floating plants and flowers like Nymphaea alba, Apium inondatum, Typha latifolia, 
Sparganium erectum (White Water Lily, Lesser Marshwort, Bulrush, Branched Bur-reed), giving birth to a locus amoenus (a beautiful place with trees, grass, fruits, flowers and water, Figure 14).

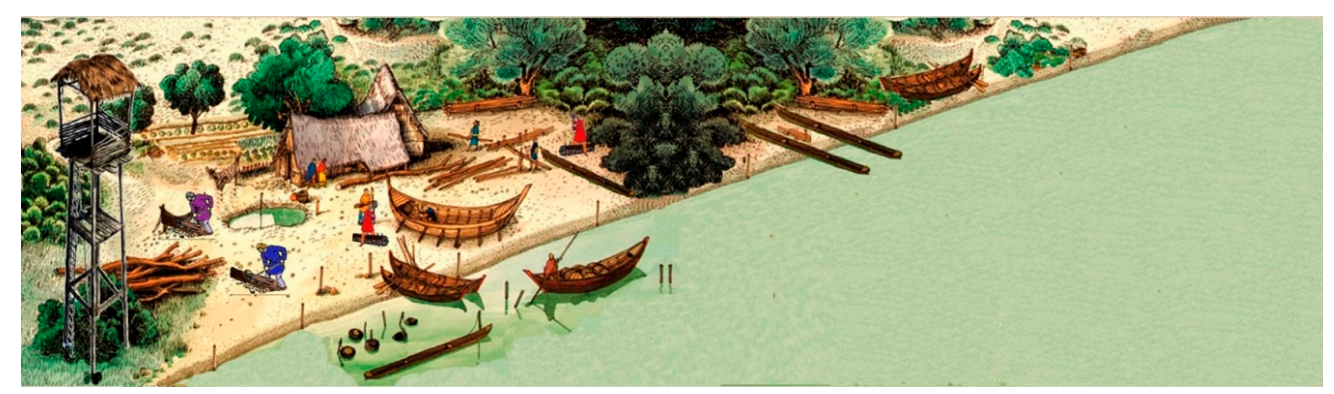

Figure 14. Paleoevirnmental and archaeological reconstruction of the North bank of the Eridanus, actually corresponding to the North side of Lago Tramonto (draw elements by R. Merlo, elaborated by G. Bucci).

Funding: This research received no external funding.

Acknowledgments: A special thanks to the Executive Board of Soprintendenza Archeologia, Belle Arti e Paesaggio per la città metropolitana di Bologna e le province di Modena; Reggio Emilia e Ferrara with F. Berti, Archaeologist, ex Director of the National Archaeological Museum of Ferrara; V. Nizzo and C. Guarnieri Functionaires, Archaeologists, A. Rosa, underwater technical assistant of Soprintendenza, A. Slanzi Gamper, owner of Tramonto Lake, F. Facchini, geological drillings technical assistant and all the Federation ITA F07 CMAS Diving Center Italia Instructors and Divers who worked on this project especially R. Bonora, A. Ferrari, A. Duccoli t. To Antonio Duccoli, passed away unexpectedly on February 2020, we would like to dedicate this work.

Conflicts of Interest: The authors declare no conflict of interest.

\section{References}

1. Destro, M. Boschi e legname tra antichità e Medioevo: Alcuni dati per l'Appennino umbro-marchigiano settentrionale. In Ocnus. Quaderni della Scuola di Specializzazione in Archeologia; CLUEB: Bologna, Italy, 2004; pp. 77-94.

2. Destro, M. Costruzione di navi e approvvigionamento di legname nelle Variae di Cassiodoro. Riv. Di Topogr. Antica 2005, XV, 107-118.

3. Mensing, S.A.; Schoolman, E.M.; Tunno, I.; Noble, P.J.; Sagnotti, L.; Florindo, F.; Piovesan, G. Historical ecology reveals landscape transformation coincident with cultural development in central Italy since the Roman Period. Sci. Rep. 2018, 8, 2138. [CrossRef] [PubMed]

4. Bucci, G. Remote Sensing and Geo-Archaeological Data: Inland Water Studies for the Conservation of Underwater Cultural Heritage in the Ferrara District, Italy. Remote Sens. 2018, 10, 380. [CrossRef]

5. Bondesan, M.; Masè, G. Geomorfologia del territorio di Voghenza e di Voghiera. In Voghenza. Una Necropoli di età Romana nel Territorio Ferrarese; Banca Credito Agrario: Ferrara, Italy, 1984; pp. 11-22.

6. Calabrese, L.; Centineo, M.C.; Cibin, U. Note Illustrative della Carta Geologica d'Italia Alla Scala 1:50.000, Foglio 204, Portomaggiore; ISPRA Progetto CARG, Regione Emilia Romagna: Firenze, Italy, 2009.

7. Luetti, R.; Veronese, T.; Brunaldi, R. PSC 5 Comuni; Relazione Geologica: Ferrara, Italy, 2005.

8. Stefani, M. Il contesto paleostratigrafico e Sedimentologico-Stratigrafico della Necropoli Romana del Verginese. In Mors Inmatura: I Fadieni e il loro Sepolcreto; Quaderni di Archeologia dell'Emilia Romagna; Berti, F., Ed.; All'Insegna del Giglio: Borgo San Lorenzo, Italy, 2006; pp. 41-47.

9. Patitucci Uggeri, S. Carta Archeologica Medievale del Territorio Ferrarese, I, Formae Italiae Medii Aevi F.76 (Ferrara); All'Insegna del Giglio: Firenze, Italy, 2002; pp. 25-27.

10. Patitucci Uggeri, S. La Romanizzazione dell'antico delta padano-aggiornamento archeologico. In Atti dell'Accademia delle Scienze di Ferrara; AA 193, 2015-2016; Accademia delle Scienze di Ferrara: Ferrara, Italy, 2016; pp. 53-78. 
11. Bucci, G. Monitoraggio archeologico subacqueo nelle acque interne del territorio ferrarese. In Atti Convegno Antichi Romani e Romanità Nelle Terre Del Delta Del Po. Nuovi Studi e Prospettive Di Ricerca; Ceserano, M., Vallicelli, M.C., Zamboni, L., Eds.; 26 Settembre 2015-Copparo (FE); Ante Quem: Bologna, Italy, 2018; pp. 127-136.

12. Bucci, G. Archeologia subacquea e geomatica per la ricostruzione del paesaggio fluviale ferrarese nella Tarda Antichità: Tecniche data fusion, indagini dirette e indirette. Archeomatica 2018, 9, 10-14.

13. Bucci, G. Padus, Sandalus, Gens Fadiena. underwater surveys, in palaeo-watercourses (Ferrara DistrictItaly). In Proceedings of the the International Archives of the Photogrammetry, Remote Sensing and Spatial Information Sciences, 2015 Underwater 3D Recording and Modeling, Piano di Sorrento, Italy, 16-17 April 2015; Volume XL-5/W5, pp. 55-60, The International Archives of the Photogrammetry, Remote Sensing and Spatial Information Sciences. [CrossRef]

14. Berti, F. (Ed.) Mors inmatura: I Fadieni e il loro sepolcreto. In Quaderni di Archeologia dell'Emilia Romagna; All'Insegna del Giglio: Sesto Fiorentino (FI), Italy, 2006.

15. Bucci, G. Archeologia preventiva e controllo archeologico in corso d'opera: Nuove scoperte nel territorio di Voghiera (FE). insediamenti rurali, aree produttive, necropoli. In Atti dell' Accademia delle Scienze di Ferrara; Accademia delle Scienze di Ferrara: Ferrara, Italy, 2018; pp. 191-221.

16. Bucci, G. Gambulaga 2009. Archeologia subacquea delle acque interne: Bacini artificiali e controllo archeologico. Osservazioni metodologiche, tecniche e stratigrafiche. In Felix Ravenna; Edizioni del Girasole: Ravenna, Italy, 2009; pp. 171-188.

17. Campana, S.R.L. Mapping the Archaeological Continuum Filling 'Empty' Mediterranean Landscapes. In Springer Briefs in Archaeology; Springer International Publishing: Cham, Switzerland, 2018.

18. Campana, S. Remote sensing: Aerial photography and satellite imagery. In Seeing the Unseen; Campana, S., Piro, M., Eds.; Taylor \& Francis Group: London, UK, 2009; pp. 273-278.

19. Parmegiani, N.; Poscolieri, M. Studio del territorio quale strumento per investigare le relazioni tra siti archeologici e ambiente circostante. In Remote Sensing in Archaeology-XI Ciclo di Lezioni Sulla Ricerca Applicata in Archeologia, Certosa di Pontignano, Siena, 6-11 Dicembre 1999; Campana, S., Forte, M., Eds.; Edizioni all'Insegna del Giglio: Firenze, Italy, 2003; pp. 144-163.

20. Bucci, G. Low visibility underwater archaeological researches: Gambulaga Project 2009-2010. In Proceedings of the 4th International Symposium on Underwater Research by Eastern Mediterranean University, Famagusta, Northern Cyprus, Famagusta, Cyrpus, 18-20 March 2010; pp. 21-38.

21. Campana, S.; Forte, M.; Liuzza, C. (Eds.) Space, Time, Place. In Proceedings of the Third International Conference on Remote Sensing in Archaeology, Tiruchirappalli, Tamil Nadu, India, 17-21 August 2009.

22. Berti, F. Rinvenimenti di archeologia fluviale ed endolagunare nel Delta Ferrarese. In Bollettino d'Arte, Supplemento, Archeologia Subacquea 3; Istituto Poligrafico e Zecca dello Stato - Archivi di Stato: Roma, Italy, 1987; pp. 19-38.

23. Marchesi, M. Imbarcazioni monossili e vie d'acqua interne nel delta del Po. In Ocnus. Quaderni della Scuola di Specializzazione in Archeologia; 1995; pp. 109-123.

24. Martire, A. Available online: https://sketchfab.com/search?q=piroga\&sort_by=-pertinence\&type=models (accessed on 10 March 2020).

25. Nanni, G. Bosco Fossile di Sandalo (Ferrara-Nord Italia). Analisi Xilologiche, Considerazioni Vegetazionali e Cenni Storici e Geomorfologici sul Territorio, Bachelor's Thesis, Alma Mater Studiorum University of Bologna, AY 2001-2002, Bologna, Italy, 2002.

26. Ceserano, M. Comacchio (FE), Area della Pieve di Santa Maria in Padovetere. Trovate due Imbarcazioni Lignee Databili tra L'età Romana e L'altomedievale. 2014. Available online: http://www.archeobologna. beniculturali.it/fe_comacchio/imbarcazioni_2014.htm (accessed on 6 February 2020).

27. Marchesini, M. Analisi Xilologica Degli Elementi Lignei Della Barca Cucita di Santa Maria in Padovetere. Available online: http://www.archeobologna.beniculturali.it/fe_comacchio/imbarcazioni_2014.htm (accessed on 10 March 2020).

28. Forlani, L.; Bandini Mazzanti, M. Indagini paleobotaniche. In Voghenza. Una Necropoli di età Romana nel Territorio Ferrarese; Banca Credito Agrario: Ferrara, Italy, 1984; pp. 315-319.

29. Bayeux Tapestry. Available online: https://en.wikipedia.org/wiki/Bayeux_Tapestry_tituli (accessed on 10 March 2020). 
30. Facchini, F. Caratterizzazione Sedimentologica e Geochimica nel Contesto Archeologico del Lago Tramonto a Gambulaga-Portomaggiore (FE). Master's Thesis, Quaternario, Preistoria e Archeologia, University of Ferrara, Ferrara, Italy, 2017.

31. Baldoni, G. Una Lucerna romana con raffigurazioni di officina vetraria: Alcune considerazioni sulla lavorazione del vetro soffiato. J. Anc. Glass Stud. 1987, 29, 22-29.

(c) (C) 2020 by the author. Licensee MDPI, Basel, Switzerland. This article is an open access article distributed under the terms and conditions of the Creative Commons Attribution (CC BY) license (http://creativecommons.org/licenses/by/4.0/). 